\title{
Educational Software to Teaching-Learning the Zapotec Language of the Istmo of Tehuantepec
}

\author{
Edgar Manuel Cano Cruz, Juan Gabriel Ruiz Ruiz \\ Computer Science Department, University of the Istmo Region, Ixtepec, Mexico
}

Email address:

ie.edgarcano@gmail.com (E. M. C. Cruz)

\section{To cite this article:}

Edgar Manuel Cano Cruz, Juan Gabriel Ruiz Ruiz. Educational Software to Teaching-Learning the Zapotec Language of the Istmo of Tehuantepec. Science Journal of Education. Vol. 3, No. 2, 2015, pp. 16-21. doi: 10.11648/j.sjedu.20150302.11

\begin{abstract}
Mexico is one of the countries with more linguistic wealth in the world, a contradiction in discriminatory behavior on the part of our urban indigenous community. This article proposes the Web design and development of educational software tool for teaching and learning Zapotec language of the Istmo of Tehuantepec in Oaxaca state. In order to contribute to increased instructive acquis on electronic media, as well as the diffusion, promotion and preservation of cultural heritage of the Istmo of Tehuantepec through learning and Zapotec language use. The development of the educational tool was performed using the methodology of User-Centered Design (UCD) to cover the functionality of the software based on the context of potential users.
\end{abstract}

Keywords: Cultural Dissemination, Zapotec Language, Educational Technologies, Web Design, User-Centered Design

\section{Introduction}

According with UNESCO's Endangered Languages Program, about half of the 6,000-plus languages spoken today will disappear by the end of this century worldwide [1]. In Mexico, about six millions of people speak a mother tongue [2]. The CIESASs web site shows that: "around of 60 native languages in Mexico are at risk, critically endangered 21 of these, with only a few elderly speakers left," (see Fig. 1).

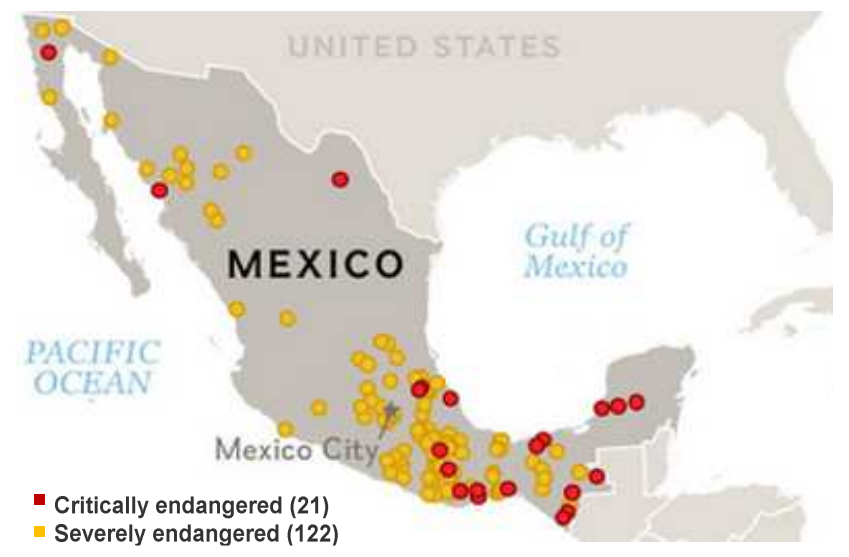

Figure 1. Languages of Mexico in endangered.

The languages most at risk in Mexico, including the Zapotec, the Chatino, and the Seri's tongues are undergoing fast change for a number of reasons. Among them are migration, social instability, and economic and ideological factors that push speakers to adopt Spanish [3].

The linguist David Harrison, co-leader of National Geographic's Enduring Voices project, mentioned "It is vital to saving mother tongues because they are the primary conduit for human culture" [4]. Mexico is a good example of this situation. In this sense, to preserve Mexico's threatened languages there should be an integrated policy that involved bilingual education technologies and design of school curricula [5]. Many Mexicans may have less interest in their region's native tongue, one of the main reasons is because Spanish is the dominant language typically taught Spanish in school.

In Mexico, the lack of outreach and implementation of policies based on multilingualism, are one of many factors that generate racial problems caused by urban populations [6]. Likewise, the educational services and teaching methods provided to the indigenous population, usually respond to a colonial vision. The main materials used to promote learning are mostly written in Castilian, making impossible to expand the communicative functions of the Mother tongues.

These elements affect the little or null interest to the cultural richness and disowning the indigenous community about their mother tongues. The long-term consequences caused by these 
social phenomena in Mexico, given as a result of the loss of the mother tongue and therefore in the lack of identity [5].

Specifically, the Istmo of the Tehuantepec region is the narrowest part of Mexico; is located southeast, in the state of Oaxaca. Although the language Zapotec in this is one of the languages with the greatest number of speakers in Mexico [2].

The trend in the growth disused problems of the Zapotec language for fear of discrimination; to the small number of spaces in which is practiced (limited to family and community contexts). Also, the absence of education and teaching methods provided to the indigenous population, will contribute to the long-term at the imminent demise of the Zapotec language.

In this article, we propose the design and development of educational software for teaching-learning Zapotec language of the Istmo of the Tehuantepec region. The objective of this tool is to contribute to the increase of the stock of teaching materials in electronic media with the aim of promoting and preserving the cultural heritage of the Istmo region in Mexico.

The educational software system is intended for users between 6 to 11 years old. In order to arouse the interest of the infants in the Zapotec culture through its language and raise awareness in the younger generation to non-discrimination of ethnic groups.

The rest of the paper is organized as follows: Section 2 shows realted work about of teaching-learning indigenous languages; Section 3 presents the design and development of the educational software; Section 4 presents the results of the educational prototype system, and finally, Section 5 concludes this paper.

\section{Related Work}

In Mexico, with the aim of contributing to the recovery, preservation and strengthening of indigenous languages and avoid possible extinction, have been implemented various projects that contributed to development educational material. Harrison has been working with a team of linguists, to build a talking dictionary for Zapotec speakers in the Tlacolula Valley [7]. Harrison considers the Zapotec speakers "a great example of how endangered language communities are leveraging new technologies-especially smartphones - to maintain their heritage languages."

In the work [8], the authors propose the design of a semiotic model to introduce multimedia learning objects to the process Zapotec language. These multimedia objects provide an ethnic context that fosters Indian children's learning, providing a multimedia material to support bilingual education in the Mixtec region of Oaxaca State. The Coalition of Indigenous Teachers and Promoters of Oaxaca (CMPIO), presents the project "Language Nest, an Intercultural Dialog on Indigenous Education between Chomsky, Anthropologists, and Educators". This project aims to revive the language and culture of the communities Cuicatec, Mixtec, Mazatec and Zapotec of the Sierra Norte region. The developed of these nests are in spaces that recreate the activities of daily life [9]. Teaching materials (brochures and booklets of songs) used figures placed in the context of the community for teaching. The website [10], is a compilation realized by Oscar Toledo Esteva and family. This site shows a translator in Spanish-Zapotec, Zapotec-Spanish, Zapotec-English and English-Zapotec. However, the website design is not adequate to allow children learn the Zapotec language and have no activities within the context of the same.

In the research [11], the authors propose an educational software for teaching-learning Zapotec language of the Mixtec region. This educational software by using open source technologies, in order to establish a way to spread the language in preschool children and first grade. The activities were created in the software for students and teachers to work together in an educational learning environment. The Research Center and Higher Studies in Social Anthropology (CIESAS), has a laboratory called "The Digital Archive of Indigenous Languages" [12]. This laboratory is website that provides digital material that allows to collect, protect and organize data of indigenous languages in Mexico. The aim of promoting the rescue and Otomi language teaching in the state of Querétaro. However, efforts have been insufficient both in education and cultural aspects, as advances are minimal compared to the spaces dedicated to learning the Spanish language.

\section{Framework}

Agree with the learning strategies raised at [13-14], has been chosen to perform an educational software where the main users are children aged between 6-11 years. In this sense, the proposed activities are based on teaching methodologies learner-centered.

The learner-centered strategies include activities, techniques and resources that take into account the motivations of the students; and their needs and interests, where the students work at different rates and with different interests. In this context, teaching models applied in bilingual schools, do not encourage the use of technological tools to support the learning process, but rather apply the traditional models of instruction, which only seeks to memorize rather than reflect on what learned [15]. Thus, the traditional model has consequences in the low or zero interest of children in their motivation for learning the Zapotec language (see Fig.2).

The design of the proposed system is oriented in ways that enhance the motivation of the children in their learning process. To do this, we use an approach where the content material provides authentic learning experiences.

The proposed system adapts aspects of educational methodology Mexican PRONALEES [16], which seeks to improve reading comprehension and writing, also developing the logical thinking, oral and written expression, and active participation. The constructivist learning model of Jean Piaget [15] is the core of PRONALES methodology on which seeks that the students provide sense of what they learned. The role of the student changes from a passive state to active, being the lead author of the acquisition of reading and writing. On the other hand, the teacher's role is that of motivator and guide the 
student in the learning process (see Fig. 3).

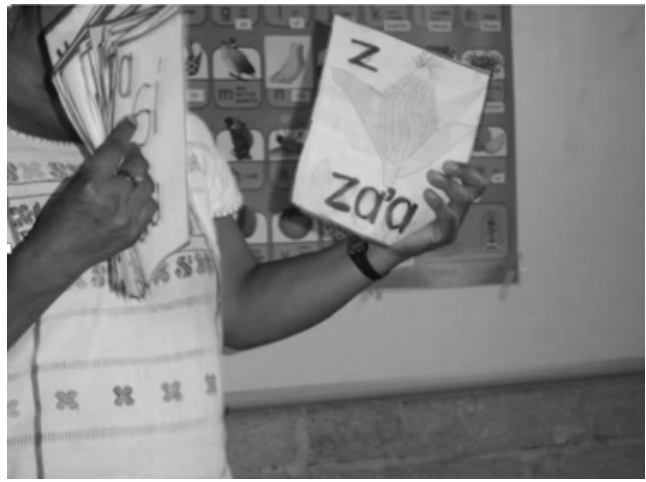

a) Traditional methods.

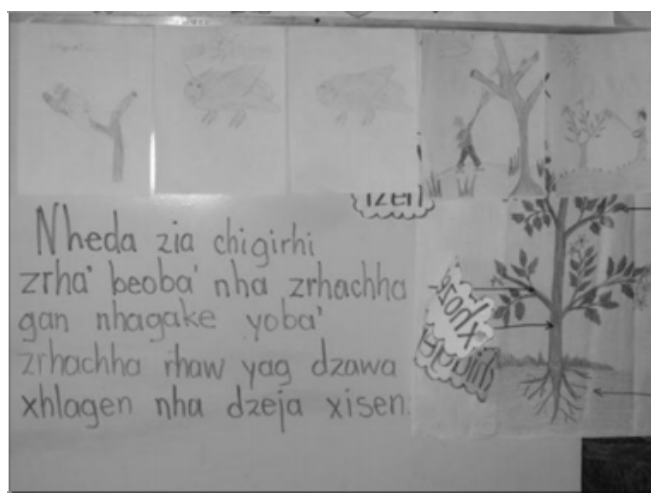

b) Traditional activities in class.

Figure 2. Activities for teaching the Zapotec language in the community.

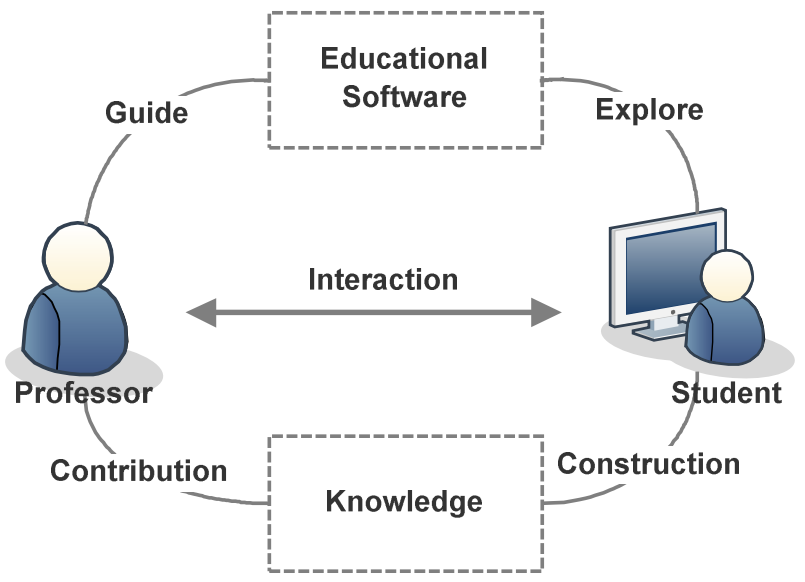

Figure 3. Model teaching-learning system.

The activities within the education system were adapted from the book by the teacher [14]. In this book, the authors explain how to address issues in the early years of children's learning, and they can understand the information in easy way. The elements suggested by the book are:

- Children should hear a lesson and view a series of images.

- Children should observe a series of letters or moving words.

- Match words with pictures.
- Put words on the appropriate image.

- Form words with a mobile alphabet related to a particular object.

- Games (Crosswords), working with crosswords can encourage reflection on the phoneme-spelling correspondence.

- Moreover, to discovery of the sound value of words, tokens and memory games of words are used.

\section{Design and Development}

For the design and development of the educational software was used the methodology User-Centered Design (UCD) [14], to define functionality of the software based on the regional context of the community of the Istmo of Tehuantepec. The methodology has four phases: Study, Design, Build and Evaluation (see Fig. 4).

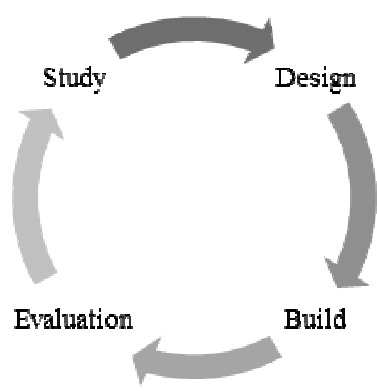

Figure 4. UCD methodology.

In the study phase, we identified several issues with the research ethnographic approach, we realize an analysis of the needs regarding educational materials for teaching Zapotec language. Also, we study the cultural reality of the Istmo region to under-stand the most significant events from the children.

To examine the motivations of professors to use the educational software pro-posed, we applied surveys and reviews of our sections. The main objective was to identify writing and reading problems related to language usage; to accomplish this task six research questions were established:

- What teaching method is used by the teacher in the Zapotec alphabetization process?

- What activities are performed in the Zapotec alphabetization process?

- What material and didactic instruments are used by the teacher in his/her educational practice?

- What doubts do children have for writing and reading in the Zapotec language?

- What observations do teachers make to children for writing and reading the Zapotec language?

- Does literacy education in Zapotec have the same relevance as in Spanish?

- What do children think of the texts and drawings that they produce in the classroom?

In the design phase, once reading and analyzed surveys and didactics materials, we identify four main topics where the 
professors interact every day with their students to teach Zapotec.

The creation of characters and scenarios of the educational software, we collect a set of drawings made by children from the community. Then, we establish the characters and scenarios that reflect the sociocultural context of them (see Fig. 5).

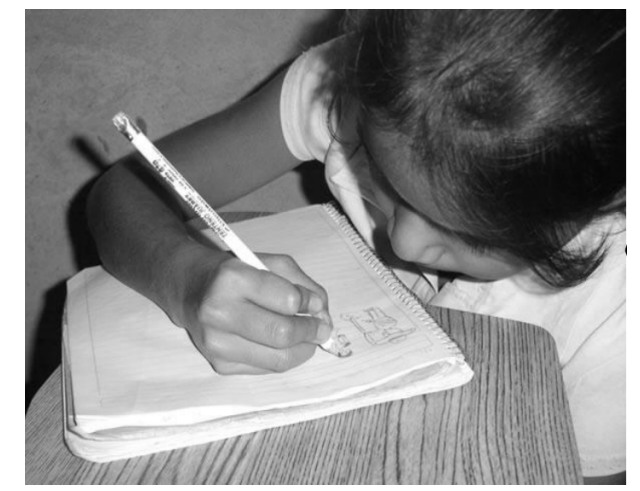

Figure 5. Zapotec children drawing a typical communal environment

The selection of the software content was design with the support and collaboration of indigenous teachers of the Istmo region. The main learning activities follow:

1. Identification of the instructional problem.

2. Set the students' characteristics.

3. Perform an analysis of tasks.

4. Identify instructional objectives.

5. Establish the sequences of the educational content.

6. Design the evaluation's functionalities.

7. Plan messages and establish a way to communicate them.

8. Establish resources to support the learning task.

For the build phase, we chosen the programming language Javascript technology to translate educational content through dynamic activities and gives functionality.

To successfully incorporate technology into the elementary indigenous school, the instructional learning activities used for developing the educational material has to take into consideration various entities, such as; knowledge and skills, socialization, environment, learning outcomes, selecting materials, pedagogical strategies, system/children response and evaluation approaches.

Following this approach, our educational software is based on four sections that enable us to establish a basis for didactic material respecting the indigenous language, traditions and context.

The main sections are: "Hralidxe" (my home), "Ca binnilidxi" (the family), "Manigui'shi" (the animals) and "Yágaguie" (plants with flowers). The Fig. 6 shows the sections mentioned.

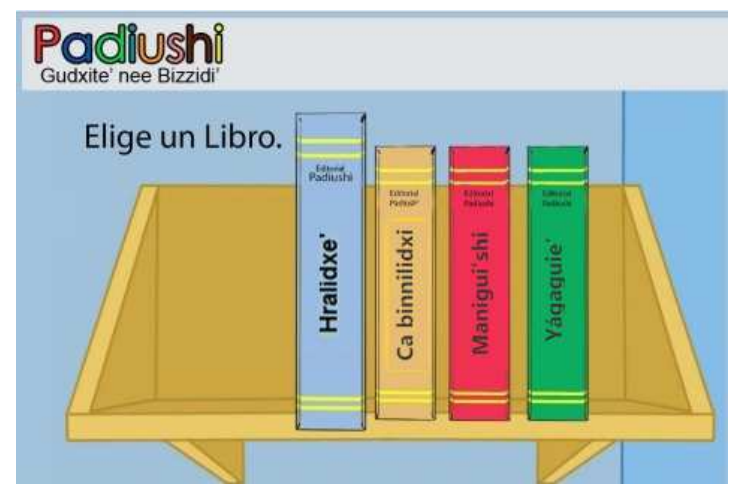

Figure 6. Sections of the educational software.

In this regard, we establish three subsections for every main section of the educational software. In this sense, the children learn vocabulary in relation to the objects in the area.

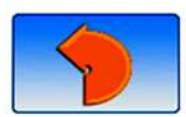

\section{Hralidxe'}
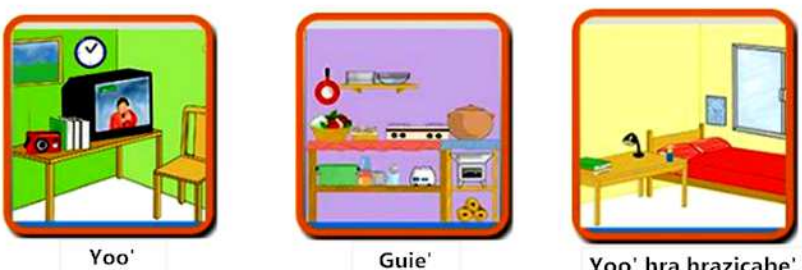

Yoo' hra hrazicabe'

Figure 7. Home Subsection.

In every subsection, we program three kind of games called Activities Zone (Zona de Actividades). In the activities zone the students interact with dynamic functionalities and they have to resolve problems, like to associate objects with your name in Zapotec or memory words in Zapotec language through a memory game, or learn the names of the primary colors in Zapotec through to paint a figure (see Fig.8)

In the evaluation phase, we verify the earliest version of the educational software through a heuristic evaluation [17]. Also, our software has verified by testing to ensure that the graphic and textual components show the correct communicability interfaces and transmit efficiently the intent of the educational content.

The results of our beta testing were analyzed on a school day and showed that interfaces with greater communicability problems were those that concentrate more on graphical and textual components.

The objective of the communicability tests was to verify that the children interacted with the graphic and text components of the educational software in the manner that the designers had intended. When the kids interpreted the functions of graphic and text components differently than what was intended, we tried to identify what might have confused them. Participants were asked for suggestions on how to correct deficiencies. 


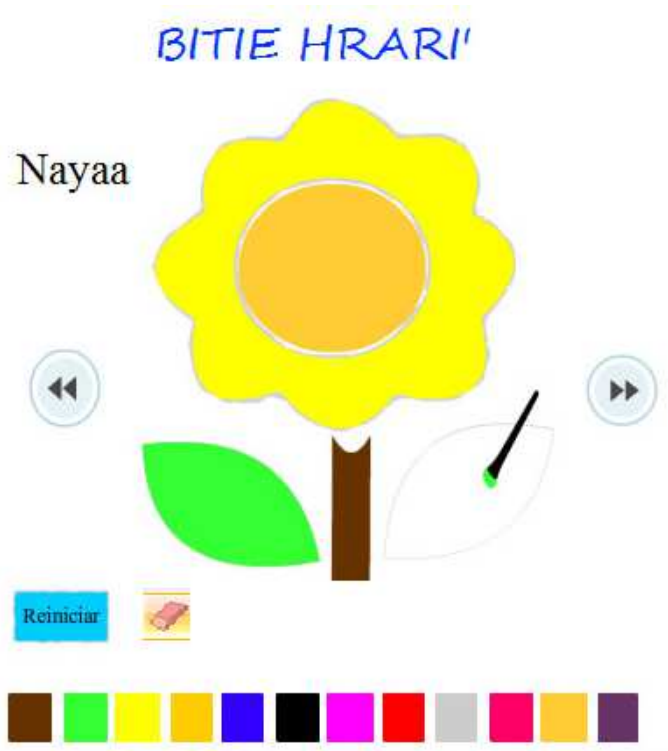

Figure 8. Paint game called BITIE HRARI'.

\section{Results}

We applied a test of an early version of our system to obtain a primary results. The experiment was performed at the final of a real course. We selected 30 children of the first year and between 6 to 8 ages of the bilingual school in the Istmo of Tehuantepec community. One group of 15 students (10 boys and 5 girls) used the educational software; this group was call 'Group A'. Other group, of 15 students (12 boys and 8 girls) don't use our system; this group was call 'Group B'. The children of both groups are 6 to 10 ages. This test began with the Group A using the game bitie hrari' (Paint flowers) of the Yágaguie' section. Then, both groups applied a quiz test about writing 8 sentences with the names of primary colors in Zapotec.

The results reveal to us that for the Group A, they wrote 7 sentences correctly. While Group B wrote 3 sentences correctly (see Fig. 9).

As preliminary results, we have performed a final evaluation to these two groups. In the Group A, 76\% passed the writing tests, and $90 \%$ passed the reading tests. In the Group B, 40\% passed the writing tests, and 50\% passed the reading tests. In some words, Group B has written more number of words incorrectly, and orthographic mistakes were detected in comparative with Group A

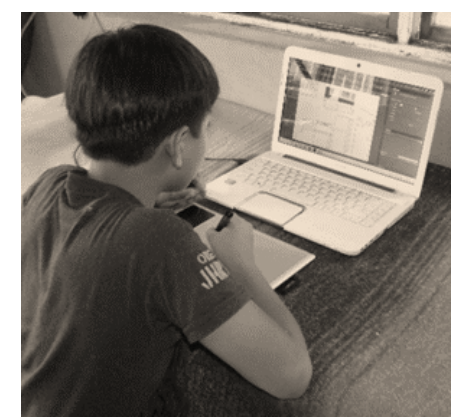

Figure 9. Zapotec child using our educational software.

\section{Conclusions}

The role played by the UCD approach in the design of our the educational software was fundamental; it allowed us to understand the teaching and learning problems that teachers and students had in the course of the Zapotec language program.

The methodology used for teaching the Zapotec language is suitable. However, it needs the support of activities and didactic material to improve children's learning process. Given that all communities are located in marginal zones, there are neither personal computers nor access to technology.

As future work will be implemented our system online adding music and video applications to improve user interaction. In the same way, will adapt the educational software to the mobile version. Furthermore, we will propose the design and development of tools for other Indian languages based on this system introduced.

\section{References}

[1] C. Dell'Amore, "Sixty Languages at Risk of Extinction in Mexico-Can They Be Kept Alive?" National Geographic, $2014 . \quad$ [Online]. Available: http://news.nationalgeographic.com/news/2014/04/140410-me xico-languages-speaking-cultures-world-zapotec/. [Accessed 2015].

[2] INEGI, "National Institute of Statistics and Geography (Mexico)," $2014 . \quad$ [Online]. Available: http://www.inegi.org.mx/. [Accessed 2015].

[3] CIESAS, "Centre of Research and Higher Studies in Social Anthropology," 2014. [Online]. Available: http://www.ciesas.edu.mx/. [Accessed 2015].

[4] National Geographic, "Enduring Voices," 2014. [Online]. Available:

http://travel.nationalgeographic.com/travel/enduring-voices/. [Accessed 2015].

[5] M. E. López-Gopar, N. Jiménez-Morales and A. Delgado-Jiménez, "Critical Classroom Practices: Using "English" to Foster Minoritized Languages and Cultures in Oaxaca, Mexico," in Minority Languages and Multilingual Education, vol. 18, Springer Netherlands, 2014, pp. 177-199.

[6] A. Henry, "The Problematics of Multiculturalism in a Post-Racial America," in Precarious International Multicultural Education, Sense Publishers, 2014, pp. 41-60.

[7] Lillehaugen, D. Brook, P. Munro, F. H. Lopez, R. Antonio-Ruiz and J. Antonio-Ruiz, "Tlacolula Valley Zapotec Talking Dictionary, pilot version.," 2013. [Online]. Available: http://www.talkingdictionary.org/zapotec. [Accessed 2015].

[8] I. Garcia, C. Pacheco and J. Ruiz, "Introducing an Etnosemiotic Approach to Develop Multimedia Material for Supporting the Alphabetization Process for a Mexican Indigenous Language," International Journal of Emerging Technologies in Learning;2011, Vol. 6 Issue 3, p42, pp. 42-48, 2011.

[9] L. Meyer and B. Maldonado, El nido de la lengua, orientación para sus guías, Colegio Superior para la Educación Integral Intercultural de Oaxaca, Oaxaca: UNICEF, 2009. 
21 Edgar Manuel Cano Cruz and Juan Gabriel Ruiz Ruiz: Educational Software to Teaching-Learning the Zapotec Language of the Istmo of Tehuantepec

[10] Toledo Family, "Vocabulario del idioma zapoteco istmeño (diidxazá)," $2015 . \quad$ [Online]. Available: http://www.biyubi.com/did_vocabulario.html. [Accessed Feb 2015].

[11] G. Pacheco, L. Cárdenas and F. Ruiz, "Enseñanza de la lengua Zapoteca, mediante el uso de tecnologías de software libre," Temas de Ciencia y Tecnología, vol. 15, no. 44, pp. 37-40, 2011.

[12] CIESAS, "Acervo Digital de Lenguas Indígenas," 2015. [Online]. Available: $\mathrm{http}: / /$ lenguasindigenas.mx/acerca-del-acervo-digital.html. [Accessed 2015].

[13] P. Cardona, E. Hekking and R. Núñez, "YAAK: Plataforma en línea para la enseñanza-aprendizaje y difusión de lenguas indígenas en México," in The 2011 Symposium for Teaching and Learning Indigenous Languages of Latin America, Notre Dame, 2011.

[14] P. Gómez, G. González, G. Morales and A. Díaz, Libro para el maestro, Mexico: SEP, 2004.

[15] K. Powell y C. Kalina, "Cognitive and Social Constructivism: Developing Tools for an Effective Classroom," vol. 130, $\mathrm{n}^{\circ} 2$, pp. 241-250, 2009.

[16] SEP, "Secretaría de Educación Pública," 2013. [Online]. Available: http://basica.sep.gob.mx/. [Accessed Feb 2015].

[17] NNG, Nielsen Norman Group 2015. [Online]. Available: http://www.nngroup.com/articles/ten-usability-heuristics/. [Accessed 2015]. 